\title{
Effect of Dietary Frying Fat, Vegetable Oil and Calcium Soaps Of Palm Oil on the Productive Behavior and Carcass Yield of Broiler Chickens
}

http://dx.doi.org/10.1590/1806-9061-2020-1310

-Author(s)

\section{Villanueva-Lopez DA'}

(iD https://orcid.org/0000-0002-6457-8819 Infante-Rodríguez $\mathrm{F}^{\prime}$

(iD) https://orcid.org/0000-0002-4003-127X Nájera-Pedraza OG'

(D) https://orcid.org/0000-0003-0394-6021 Barrios-García HB'

(iD) https://orcid.org/0000-0001-7590-319X Salinas-Chavira J'

(iD https://orcid.org/0000-0002-3149-3413

Department of Animal Nutrition, College of Veterinary Medicine and Animal Science, Autonomous University of Tamaulipas, Mexico.

\section{-Mail Address}

Corresponding author e-mail address Jaime Salinas-Chavira

Universidad Autonoma de Tamaulipas Facultad de Medicina Veterinaria y Zootecnia - Nutricion Animal - km. 5 carretera $\mathrm{cd}$. victoria a $\mathrm{cd}$. mante Victoria Tamaulipas 87000 - Mexico.

Phone: +52 8343073376

Email: jsalinasc@hotmail.com

\section{- Keywords}

Broiler chicken, calcium soaps, palm oil, recycled fat, vegetable oil.

\section{ABSTRACT}

Vegetable oils (VO) and animal fats are conventional lipid sources used in feed formulations. Frying fats (FF) and calcium soaps of palm oil (CaSPO) are low-cost lipid sources. This study evaluated the productive performance of broiler chickens fed diets with CaSPO in substitution for VO or FF. Two hundred, 1-day old male broiler chickens were allocated in a randomized design with factorial arrangement (22). Diets included 2 lipid sources (FF and VO) and 2 CaSPO levels (0 and 50\%). The study had two phases (starter and finisher) of 21 days each. For the starter phase there was no effect $(p>0.05)$ of dietary treatments on the chickens' productive performance. For the finisher phase birds fed diets with FF had higher feed intake and feed conversion ratio (main effect; $p<0.01$ ) than those fed diets with VO. Over the 42-day feeding period animals fed $\mathrm{FF}$ had higher feed conversion ratio (main effect; $p=0.02)$ and tended $(p=0.08)$ to show higher feed intake than those fed diets with VO. The CaSPO substitution for VO or FF had no effect ( $p>0.05)$ on the productive performance of broiler chickens. There was no influence of treatment on carcass yield. The drumsticks plus thighs were higher (main effect; $p<0.01$ ) in birds receiving VO than in those receiving FF. The interaction (fat source ${ }^{\star} \mathrm{CaSPO}$ ) was not significant $(p>0.05)$. These results may indicate that $\mathrm{VO}$ is superior to FF and CaSPO may substitute for VO or FF without affecting productive performance of broiler chickens. Lipid source showed small influence on carcass characteristics.

\section{INTRODUCTION}

In 2018, the poultry industry in Mexico represented $63.3 \%$ of all animal production; within poultry, 34.9\% were broiler chickens. Chicken meat is a significant food source for Mexican consumers; protein intake from chicken was 39\% compared to $16 \%$ from beef and $8 \%$ from pork. In Mexico, per capita consumption in 2018 was 23 $\mathrm{kg}$ of broiler chicken meat (UNA, 2018).

Broiler chicken productive performance is improved with different energy-rich ingredients in the diet. Carbohydrates in cereal grains supply the majority of energy required by broiler chickens; however, per se, cereal grains do not cover broiler chickens' energy requirement (InfanteRodriguez et al., 2016). Lipids with high energy density are included in the diet to cover the requirements needed by highly productive broiler chickens. Animal fats, vegetable oils and a blend of both are the most common sources of lipids used in poultry diets. Vegetable oils with higher concentration of linoleic and linolenic essential fatty acids have improved growth in broiler chickens (Itzá-Ortiz et al., 2008). The main animal fat used in animal feed is beef tallow, which is obtained during meat processing for human consumption; it has a high melting 
Villanueva-Lopez DA, Infante-Rodríguez $F$, Nájera-Pedraza OG, Barrios-García HB, Salinas-Chavira J
Effect of Dietary Frying Fat, Vegetable Oil and Calcium Soaps Of Palm Oil on the Productive Behavior and Carcass Yield of Broiler Chickens point (remaining solid at room temperature), it is low in, moisture, non-fat compounds and free fatty acids (Plascencia et al., 2005).

Frying fat is a mixture of vegetable oils used in restaurants for frying food, usually for long periods of time at high temperatures. Chemical reactions of hydrolysis, oxidation and polymerization of the oils take place during the frying process; these reactions produce peroxides, reduce the unsaturation of fatty acids and increase foaming, color, viscosity, density, and concentration of free fatty acids and polar materials (Choe \& Min, 2007). To stabilize the frying fats antioxidants are used, such as butylated hydroxyanisole (BHA) and butylated hydroxytoluene (BHT) which in high concentrations might be toxic for animals (Jayalakshmi \& Sharma, 1986; Kahl \& Kappus, 1993). Frying fats that have high levels of oxidation may reduce digestibility, feed intake and feed efficiency in animals (Vázquez-Añón \& Jenkins, 2007; VázquezAñón et al., 2008, Ali et al., 2020). Nevertheless, in some cases frying fats can be used in diets for broiler chickens with feed efficiency similar to vegetable oils (Orduña-Hernández et al., 2016).

Palm oil is one of the most produced oils in the world; it is mainly used in the food industry and has partial use in animal feeds. In some areas of the world palm oil can be found at a competitive price when compared to other vegetable oils or animal fats. Previously, Valencia et al. (1993) observed adequate productive performance of broiler chickens fed diets with palm oil. More recently, calcium soaps of palm oil were produced through saponification for ruminant feeding. Calcium soaps of fats are found in granulated form, are easy to mix in diets and are resistant to oxidation (Salinas et al., 2006). Different fat and oil sources are used to produce the calcium soaps of fats. Interestingly, specific studies of calcium soaps of palm oil in diets for broiler chickens have been limited. In addition, calcium soaps of palm oil are much less expensive than conventional vegetable oils used in poultry diets. Dewi et al. (2011) reported that with a $5 \%$ of calcium-palm oils in the diet, broiler chickens fed by four weeks showed increased feed intake, whereas those fed at 15\% showed reduced feed intake; final body weight was unaffected by dietary level of calcium-palm fatty acid.

Frying fat is also less expensive than conventional vegetable oils used in poultry diets. There is no previous report on broiler chickens fed diets containing frying fat and calcium soaps of palm oil. The objective of the present study was to evaluate the productive performance of broiler chickens fed diets with substitution of calcium soaps of palm oil for common vegetable oil or frying fat.

\section{MATERIALS AND METHODS}

\section{Study area}

The study was carried out at the poultry farm of the College of Veterinary Medicine and Animal Science of the Autonomous University of Tamaulipas, in Ciudad Victoria, Tamaulipas (dry subtropical area in northeastern Mexico). The area is located at $23^{\circ} 44^{\prime} 06^{\prime \prime} \mathrm{N}$ and $97^{\circ} 09^{\prime} 50^{\prime \prime} \mathrm{W}$, at an altitude of $323 \mathrm{~m}$. The mean annual rainfall is $926 \mathrm{~mm}$, and the average temperature is $24^{\circ} \mathrm{C}$ (INEGI, 2017). These climatic characteristics are typical for the dry subtropics (ACW).

\section{Management and diets}

All procedures involving animal care and management were approved by the Bioethics Committee of the College of Veterinary Medicine and Animal Science of the Autonomous University of Tamaulipas.

Two hundred, 1-day-old male Ross broiler chickens weighing $41.3 \pm 1.34 \mathrm{~g}$ on average were obtained from a commercial hatchery. Each treatment (diet) included 50 birds randomly assigned with five replicates of ten animals each. During the entire experiment, birds were housed in 20 floor pens with ground grass straw as litter. Twenty-four hours of light per day were provided during the entire trial. Each pen had an automatic drinker and a manually-filled feeder. Space allocation was at ten birds per square meter. Water and feed were offered ad libitum. Birds were vaccinated on day 7 of the trial against fowl pox (wing puncture) and against Newcastle (ocular) using the La Sota strain.

The chickens were raised following standard commercial practice. Two feeding phases were used: 1-21 and 22-42 days of age, for starter and finisher phases, respectively. There were four treatments $(T)$ for starter and finisher diets. The only difference between experimental diet composition was the lipid source: in $\mathrm{T} 1$ it was $100 \%$ vegetable oil (VO), whereas T2 included $50 \% \mathrm{VO}+50 \%$ Ca soap of palm oil (CaSPO), T3 contained $100 \%$ Frying fat (FF), and T4 had 50\% $\mathrm{FF}+50 \%$ CaSPO. Diets were prepared according to the National Research Council (NRC, 1994) poultry recommendations and are shown in Tables 1 and 2 .

Body weight and feed intake were measured weekly and feed conversion ratio (FCR; feed intake, g/weight gain, g) was calculated. At the end of the trial, two 
Villanueva-Lopez DA, Infante-Rodríguez F, Nájera-Pedraza OG, Barrios-García HB, Salinas-Chavira J

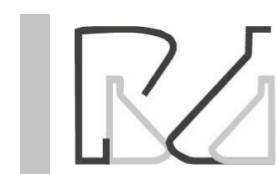

Effect of Dietary Frying Fat, Vegetable Oil and

Calcium Soaps Of Palm Oil on the Productive Behavior and Carcass Yield of Broiler Chickens

Table 1 - Contents (\%) of broiler experimental diets for the starter phase (1-21 days of age).

\begin{tabular}{|c|c|c|c|c|}
\hline \multirow[b]{2}{*}{ Ingredients } & \multicolumn{2}{|c|}{ Vegetable oil } & \multicolumn{2}{|c|}{ Frying fat } \\
\hline & $0 \% \mathrm{CaSPO}^{1}$ & $50 \%$ CaSPO & $0 \%$ CaSPO & $50 \%$ CaSPO \\
\hline Sorghum grain & 58.9 & 58.9 & 58.9 & 58.9 \\
\hline Soybean meal & 33.7 & 33.7 & 33.7 & 33.7 \\
\hline Vegetable oil (VO) & 3.4 & 1.7 & 0 & 0 \\
\hline Frying fat (FF) & 0 & 0 & 3.4 & 1.7 \\
\hline Ca soap of palm oil (CaSPO) & 0 & 1.7 & 0 & 1.7 \\
\hline Premix* & 4 & 4 & 4 & 4 \\
\hline Total & 100 & 100 & 100 & 100 \\
\hline \multicolumn{5}{|l|}{ Nutrient composition } \\
\hline Crude protein, \% & 21.4 & 21.4 & 21.4 & 21.4 \\
\hline $\mathrm{ME}, \mathrm{kcal} / \mathrm{kg}$ & 3040 & 3040 & 3040 & 3040 \\
\hline
\end{tabular}

${ }^{1}$ Calcium soaps of palm oil (CaSPO)

*Premix: monocalcium phosphate, calcium carbonate, common salt, growth promoter (BDM and 3-nitro), sodium monensin, mineral oil, ethoxyquin, retinol (vitamin A-acetate), cholrcalciferol-D3 (vitamin D3), $\alpha$-tocopheryl acetate (vitamin E), vitamin K3, riboflavin (vitamin B2), cobalamin (vitamin B12), niacin (vitamin B3), calcium D-pantothenate (vitamin B5), choline chloride (vitamin B4), butylated hydroytoluene (BHT). Calculated to contain: $21.40 \%$ Ca; $8.10 \%$ total P; $3.40 \%$ Na; 0.80\% L-lysine chlorhydrate; and 4.15\% DL-methionine.

Table 2 - Contents (\%) of broiler experimental diets for the finisher phase (22-42 days of age).

\begin{tabular}{|c|c|c|c|c|}
\hline \multirow[b]{2}{*}{ Ingredients } & \multicolumn{2}{|c|}{ Vegetable oil } & \multicolumn{2}{|c|}{ Frying fat } \\
\hline & $0 \% \mathrm{CaSPO}^{1}$ & $50 \%$ CaSPO & $0 \% \mathrm{CaSPO}$ & $50 \%$ CaSPO \\
\hline Sorghum grain & 65.6 & 65.6 & 65.6 & 65.6 \\
\hline Soybean meal & 26.4 & 26.4 & 26.4 & 26.4 \\
\hline Vegetable oil (VO) & 3.7 & 1.85 & 0 & 0 \\
\hline Frying fat (FF) & 0 & 0 & 3.7 & 1.85 \\
\hline Ca soap of palm oil (CaSPO) & 0 & 1.85 & 0 & 1.85 \\
\hline Premix* & 4 & 4 & 4 & 4 \\
\hline Pigment & 0.33 & 0.33 & 0.33 & 0.33 \\
\hline Total & 100 & 100 & 100 & 100 \\
\hline \multicolumn{5}{|l|}{ Nutrient composition } \\
\hline$C P, \%$ & 18.7 & 18.7 & 18.7 & 18.7 \\
\hline ME, kcal & 3120 & 3120 & 3120 & 3120 \\
\hline
\end{tabular}

${ }^{1}$ Calcium soaps of palm oil (CaSPO)

*Premix: monocalcium phosphate, calcium carbonate, common salt, growth promoter (BDM and 3-nitro), sodium monensin, mineral oil, ethoxyquin, retinol (vitamin A-acetate), cholrcalciferol-D3 (vitamin D3), $\alpha$-tocopheryl acetate (vitamin E), vitamin K3, riboflavin (vitamin B2), cobalamin (vitamin B12), niacin (vitamin B3), calcium D-pantothenate (vitamin B5), choline chloride (vitamin B4), butylated hydroytoluene (BHT). Pre-mix calculated to contain: 19.80\% Ca; 3.70\% total P; 3.70\% Na; 4.33\% L-lysine chlorhydrate; and 5.15\% DL-methionine.

birds per cage, selected at random, were sacrificed by cervical dislocation (Mexican official law NOM-033SAG/ZOO-2014) for carcass determinations. Carcass weight without viscera was used to estimate hot carcass yield. Then the carcass was dissected for main cuts: breast, thighs plus drumsticks, wings, and back.

\section{Statistical analyses}

The experiment consisted of four dietary treatments with five replicates each, using a completely randomized design with factorial arrangement $\left(2^{2}\right)$ of treatments. The analysis of variance considered as main effects two lipid sources (FF and VO) and two CaSPO levels (0 and 50\%) as well as the interaction of these effects. For the productive performance (weight gain, feed intake, and feed conversion ratio) the replicate was the average of all broiler chickens in each pen. For carcass evaluation the replicate was the average of two birds (selected at random) per pen. The percentage of dressed carcass yield was determined as carcass weight (g)/live weight (g). Significance was declared at $\mathrm{p} \leq 0.05$; a tendency was considered at $p>0.05$ and $p \leq 0.10$. For statistical analyses the GLM procedures of SAS (2007) were used.

\section{RESULTS}

\section{Growth performance}

Results of productive performance of broiler chickens are shown in Table 3. In the study, the interaction (Fat source*CaSPO level) was not significant $(p>0.05)$. During the starter phase (1-21 days), there was no effect ( $p>0.05$ ) of dietary treatments on weight gain, feed intake or feed conversion ratio.

For the finisher phase (21-42 days), there was no effect $(p>0.05)$ of dietary treatment on weight gain. 
Villanueva-Lopez DA, Infante-Rodríguez F, Nájera-Pedraza OG, Barrios-García HB, Salinas-Chavira J
Effect of Dietary Frying Fat, Vegetable Oil and Calcium Soaps Of Palm Oil on the Productive Behavior and Carcass Yield of Broiler Chickens

Table 3 - Effect of fat source on the productive performance of broiler chickens.

\begin{tabular}{|c|c|c|c|c|c|c|c|c|}
\hline \multirow[b]{2}{*}{ Variables and Feeding Stage } & \multicolumn{2}{|c|}{ Vegetable Oil } & \multicolumn{2}{|c|}{ Frying fat } & \multirow{2}{*}{ SEM } & \multicolumn{3}{|c|}{$p$ value main effect } \\
\hline & $0 \% \mathrm{CaSPO}^{1}$ & $50 \%$ CaSPO & $0 \%$ CaSPO & $50 \%$ CaSPO & & Fat & CaSPO & Fat*CaSPO \\
\hline \multicolumn{9}{|l|}{ Starter phase (1-21 days) } \\
\hline Weight gain, $g$ & 902 & 948 & 906 & 889 & 24 & 0.27 & 0.55 & 0.21 \\
\hline Feed intake, g & 1474 & 1589 & 1499 & 1480 & 68 & 0.55 & 0.49 & 0.34 \\
\hline $\mathrm{FCR}^{2}$ & 1.63 & 1.68 & 1.65 & 1.67 & 0.07 & 0.97 & 0.64 & 0.88 \\
\hline \multicolumn{9}{|l|}{ Finisher phase (22-42 days) } \\
\hline Weight gain, $\mathrm{g}$ & 2223 & 2291 & 2301 & 2278 & 36 & 0.65 & 0.47 & 0.90 \\
\hline Feed intake, g & 4052 & 3954 & 4309 & 4312 & 92 & $<0.01$ & 0.61 & 0.59 \\
\hline FCR & 1.74 & 1.73 & 1.88 & 1.9 & 0.05 & $<0.01$ & 0.99 & 0.70 \\
\hline \multicolumn{9}{|l|}{ Entire study (1-42 days) } \\
\hline Weight gain, $g$ & 3224 & 3239 & 3207 & 3167 & 53 & 0.41 & 0.82 & 0.61 \\
\hline Feed intake, g & 5526 & 5544 & 5808 & 5792 & 140 & 0.08 & 0.99 & 0.91 \\
\hline FCR & 1.71 & 1.71 & 1.81 & 1.83 & 0.04 & 0.02 & 0.84 & 0.83 \\
\hline
\end{tabular}

'Calcium soaps of palm oil (CaSPO)

${ }^{2} \mathrm{FCR}=$ Feed conversion ratio $=$ feed intake, $\mathrm{g} /$ weight gain, $\mathrm{g}$.

However, broiler chickens fed diets with FF had higher feed intake and feed conversion ratio (main effect; $p<0.01$ ) than those fed diets with VO.

Over the 42-day feeding period, there was no treatment effect $(p>0.05)$ on weight gain. Nevertheless, broiler chickens fed diets with FF had a higher feed conversion ratio (main effect; $p=0.02$ ) and tended $(p=0.08)$ to show higher feed intake than those fed diets with VO. The substitution of CaSPO for VO or FF had no effect $(p>0.05)$ on the productive performance of broiler chickens.

\section{Carcass characteristics}

Carcass characteristics of broiler chickens in the study are shown in Table 4. The interaction (Fat source*CaSPO level) was not significant $(p>0.05)$. There was no influence of treatment on carcass weight, carcass yield or wing yield. The drumstick plus thigh yield was higher (main effect; $p<0.01$ ) in animals receiving VO than in birds fed FF. Broiler chickens fed dietary CaSPO tended to exhibit higher breast yield (main effect; $p=0.06$ ) and lower back yield (main effect; $p=0.07$ ) than chickens not fed CaSPO.

Table 4 - Broiler chicken carcass characteristics.

\begin{tabular}{|c|c|c|c|c|c|c|c|c|}
\hline \multirow[b]{2}{*}{ Carcass evaluation } & \multicolumn{2}{|c|}{ Vegetable oil } & \multicolumn{2}{|c|}{ Frying fat } & \multirow[b]{2}{*}{ SEM } & \multicolumn{3}{|c|}{$p$ value main effect } \\
\hline & $0 \% \mathrm{CaSPO}^{1}$ & $50 \%$ CaSPO & 0\% CaSPO & $50 \%$ CaSPO & & Fat & CaSPO & Fat*CaSPO \\
\hline Hot carcass weight, g & 2434 & 2566 & 2394 & 2374 & 86 & 0.21 & 0.53 & 0.40 \\
\hline Carcass yield, \%² & 74.7 & 73.0 & 75.7 & 74.4 & 1.13 & 0.31 & 0.20 & 0.84 \\
\hline Breast yield, \% & 37.7 & 39.4 & 38.4 & 39.6 & 0.70 & 0.53 & 0.06 & 0.75 \\
\hline Thigh + drumstick yield, \% & 31.0 & 31.3 & 29.7 & 30.0 & 0.37 & $<0.01$ & 0.49 & 0.99 \\
\hline Wing yield, \% & 10.7 & 10.3 & 10.6 & 10.4 & 0.40 & 0.89 & 0.47 & 0.75 \\
\hline Back yield, \% & 19.4 & 18.4 & 19.6 & 19.3 & 0.34 & 0.13 & 0.07 & 0.40 \\
\hline
\end{tabular}

'Calcium soaps of palm oil (CaSPO)

${ }^{2}$ Percentage of dressed carcass yield $=(\text { carcass weight, } g / \text { live weight, } g)^{*} 100$

\section{DISCUSSION}

\section{Growth performance}

Broiler chickens fed diets with VO had better productive performance than birds fed diets with FF. Ali et al. (2020) also found reduced productive performance of broiler chickens fed diets with thermally oxidized palm oil when compared with broiler chickens receiving fresh palm oil in the diet. In contrast, Dorra et al. (2014) and Orduña-Hernández et al. (2016) observed similar productive performance in broiler chickens fed diets with FF or VO, attributing this response to the low levels of free fatty acids in the FF that they used. Wu et al. (2011) observed similar productive performance in broiler chickens fed diets with soybean oil or FF with low levels of free fatty acids (3\%); however, when FF had high free fatty acids levels (12\%), the broilers' productive performance was reduced. Frying fats do not have constant nutritive values because they are a blend of fats and oils obtained from different restaurants or other commercial food companies where fats and oils were subjected to varying processes during cooking. The increase in free fatty acids in fats reduces their absorption (Sklan, 
Villanueva-Lopez DA, Infante-Rodríguez $F$, Nájera-Pedraza OG, Barrios-García HB, Salinas-Chavira J
Effect of Dietary Frying Fat, Vegetable Oil and Calcium Soaps Of Palm Oil on the Productive Behavior and Carcass Yield of Broiler Chickens
1979; Baião \& Lara, 2005) and metabolizable energy in broiler chickens (Wiseman \& Salvador, 1991); these effects could be attributed to low micellar solubility or formation with the free fatty acids (Garrett \& Young, 1975; Baião \& Lara, 2005).

During the frying process of foods, fat and oils are subjected to high temperatures constantly for long periods in the presence of air. This causes chemical reactions that produce peroxides, reduce the unsaturation of fatty acids and increase polar materials (Choe \& Min, 2007). These compounds promote the degradation of fats, changing their physical-chemical properties. Oxidative rancidity or peroxidation decreases the nutritive value of fat and oils, producing undesirable odor and flavor. The iodine values and other analyses evaluate the oxidative stability of fats. Takeoka et al. (1997) observed a reduction in the iodine values of different frying fat and oils; the more unsaturated fat and oils had greater changes in iodine values. In agreement, Chebet et al. (2016) reported iodine values of 129.4 and 86.6 for soybean oil, 50.8 and 45.7 for palm oil, respectively for fresh and frying fats of chicken. Soybean oil with greater unsaturation had greater iodine values variation. In the current study the iodine values of the frying fat were not measured; however, it did not have undesirable odor, and the impurities could be low. The smaller nutritive value of frying fats compared with fresh vegetable oil in the present study could be attributed to the high amount of free fatty acids and by its greater oxidation level.

The productive performance of broiler chickens was not altered with CaSPO substituting for VO or FF. Interestingly, CaSPO did not reduce the productive performance of broiler chickens fed VO diets, nor did it improve the productive performance of broiler chickens fed FF diets. The VO of the current study contains $99.9 \%$ of fat (declared by manufacturer) while CaSPO has $84 \%$ of total fat (declared by the manufacturer); this difference in fat concentration did not influence on the productive performance of chickens. It is possible that VO complemented the intestinal fatty acid absorption of CaSPO, and it was enough to maintain the productive performance of broiler chickens in a manner similar to the birds receiving only VO. Previously it was observed that a blend of fats (recycled fat and VO) had similar effect on broiler chicken production (Waldroup et al., 1995), attributing this to a complementary effect between VO and recycled fat. Also, Poorghasemi et al. (2013) reported positive production in broiler chickens fed diets containing a combination of vegetable and animal fats.
Conversely, the productive performance of broilers was not improved by substituting CaSPO for FF. The fatty acids of triglycerides in palm oil, during the saponification process bind to calcium, thus CaSPO has lower energy concentration than palm oil. The information declared by the manufacturer of CaSPO used in this study shows a content of 8 to $9.6 \%$ calcium and $14 \%$ ash. Despite this high content of non-fat compounds in CaSPO that do not provide energy, it was not revealed in the production of the broiler chickens. Further research to elucidate these substitutions of fats is warranted. There is limited information on the dietary use of calcium soaps of palm oil in broiler chickens. For applied broiler chicken production, CaSPO is an alternative as a partial substitution for VO or FF in cases where the cost of CaSPO is competitive with the other fat sources.

\section{Carcass characteristics}

Carcass weight, carcass yield or wings yield showed no influence of dietary treatment. The greater drumsticks plus thighs in animals receiving $V O$ than in birds receiving dietary FF is consistent with improved productive performance of broiler chickens fed VO. Dorra et al. (2014) reported no effect of dietary frying fat substituting for fresh oil on carcass traits in broiler chickens. Nobakht et al. (2011) found no influence of different dietary vegetable oils on yield of carcass, breast and thigh, whereas feed efficiency was influenced by dietary oil. Similarly, Anjum et al. (2004) did not observe differences in carcass dressing percentage and organ weights in broiler chickens fed diets with fresh soybean oil or oxidized soybean oil.

In the present study, the positive effects on carcass characteristics obtained with dietary calcium soaps of palm oil are of importance in broiler chicken production. Further research on the effect of CaSPO on carcass and meat quality is warranted. Malá et al. (2004) found that the replacing vegetable oils with calcium salts of fatty acids of rape and soybean seeds produced no negative effects on carcass characteristics in broiler chickens. In other studies, calcium salts of soybean oil have not affected carcass abdominal fat in broiler chickens (Tabeidian \& Sadeghi, 2006; Mosavat et al., 2011). Information on this theme is currently limited.

\section{CONCLUSIONS}

In the present study, broiler chickens fed dietary VO had better productive performance than broilers fed FF. The substitution of CaSPO for VO or FF had no effect 
Villanueva-Lopez DA, Infante-Rodríguez $\mathrm{F}$, Nájera-Pedraza OG, Barrios-García HB, Salinas-Chavira J

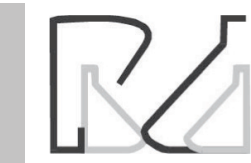

on the productive performance of broiler chickens. The fat source (VO or FF) or its substitution with CaSPO had no great influence on broiler carcass characteristics. In areas of the world where calcium soap of palm oils is less expensive than conventional vegetable oils, it represents a real alternative to formulate diets for broiler chickens. Further research considering digestive and meat parameters is warranted.

\section{ACKNOWLEDGEMENTS}

We acknowledge the Facultad de Medicina Veterinaria y Zootecnia of the Universidad Autónoma de Tamaulipas for the facilities and technical staff in the present study. The authors also want to thank Dr. Miguel Angel Domínguez Muñoz by his excellent review of the manuscript.

\section{DECLARATION OF INTEREST STATEMENT}

No potential conflict of interest was reported by the authors.

\section{REFERENCES}

Ali SAF, Ismail AA, Abdel-Hafez SA, El-Genaidy HMA. Influence of thermally oxidized palm oil on growth performance and PPAR- $\alpha$ gene expression in broiler chickens. Egyptian Academic Journal of Biological Sciences. C, Physiology and Molecular Biology 2020; 12(1):23-37.

Anjum MI, Mirza IH, Khan AG, Azim A. Effect of fresh versus oxidized soybean oil on growth performance, organs weights and meat quality of broiler chicks. Pakistan Veterinary Journal 2004; 24(4):173-178.

Baião NC, Lara LJC. Oil and fat in broiler nutrition. Brazilian Journal of Poultry Science 2005;7(3):129-141.

Chebet J, Kinyanjui T, Cheplogoi P K. Impact of frying on iodine value of vegetable oils before and after deep frying in different types of food in Kenya. Journal of Scientific and Innovative Research 2016;5(5):193196.

Choe E, Min DB. Chemistry of deep-fat frying oils. Journal of Food Science 2007;72(5):77-86

Dewi GAMK, Astawa PA, Sumadi IK. Effect of inclusion calcium-palm fatty acid (Ca-PFA) on growth performance and profile of body fatty acid of broiler. Journal of the Indonesian Tropical Animal Agriculture $2011 ; 36(1): 55-60$

Dorra TM, Hamady GAA, Abdel-Moneim MA. The use of recovered frying oil in broiler chicken diets:effect on performance, meat quality and blood parameters. Research Journal of Animal, Veterinary and Fishery Sciences 2014;2(3):11-15.

Garrett RL, Young RJ. Effect of micelle formation on the absorption of neutral and fatty acids by the chicken. Journal of Nutrition 1975;105(7):827838.

INEGI - Instituto Nacional de Estadística, Geografía e Informática. Anuario Estadístico del Estado de Tamaulipas. 2017 [cited 2020 Jan 16]. Available from: http://www.datatur.sectur.gob.mx/itxef_docs/tams_ anuario_pdf.pdf.

\section{Effect of Dietary Frying Fat, Vegetable Oil and \\ Calcium Soaps Of Palm Oil on the Productive Behavior and Carcass Yield of Broiler Chickens}

Infante-Rodríguez F, Salinas-Chavira J, Montaño-Gómez MF, ManríquezNuñez OM, González-Vizcarra VM, Guevara-Florentino OF, et al. Effect of diets with different energy concentrations on growth performance, carcass characteristics and meat chemical composition of broiler chickens in dry tropics. SpringerPlus 2016;5(1):1937.

Itzá-Ortiz MF, López-Coello C, Ávila-González E, Gómez-Rosales S, ArceMenocal J, Velásquez-Madrazo PA. Effect of energy source and level on the length of intestinal villi, immune response and the production performance in broilers. Veterinaria México 2008;39(4):357-376.

Jayalakshmi CP, Sharma JD. Effect of butylated hydroxyanisole (BHA) and butylated hydroxytoluene (BHT) on rat erythrocytes. Environmental Research 1986;41(1):235-238.

Kahl R, Kappus H. Toxicology of the synthetic antioxidants BHA and BHT in comparison with the natural antioxidant vitamin E. Zeitschrift für Lebensmittel-Untersuchung und Forschung 1993;196(4):329-338.

Malá S, Slezáčková I, Strakova E, Suchý P, Večerek V. Plant-based diets containing ca-salts of fatty acids and their influence on performance, carcass characteristics, and health status of broiler chickens. Acta Veterinaria Brno 2004;73(3):321-328.

Mosavat $\mathrm{N}$. Use of soybean fatty acids and soybean calcium salt fatty acids in broiler chickens diets. Advances in Environmental Biology 2011;5(10):3068-3071.

Nobakht A, Tabatbaei S, Khodaei S. Effects of different sources and levels of vegetable oils on performance, carcass traits and accumulation of vitamin $\mathrm{E}$ in breast meat of broilers. Current Research Journal of Biological Sciences 2011;3(6), 601-605

NRC - National Research Council. Nutrient requirements of poultry. $9^{\text {th }}$ ed. Washington: National Academy Press; 1994.

NOM - Norma Oficial Mexicana. Métodos para dar muerte a los animales domésticos y silvestres [NOM-033-SAG/ZOO-2014]. 2014 [cited 2020 Jun 19]. Available from: https://www.gob.mx/cms/uploads/attachment/ file/203456/NOM-033-SAGZOO-2014_260815.pdf.

Orduña-Hernández HM, Salinas-Chavira J, Montaño-Gómez MF, InfanteRodriguez F, Manríquez-Núñez OM, de la Luz Vazquez-Sauceda M, et al. Effect of frying fat substitution by vegetable oil and energy concentration on diets for productive performance of broilers. Ciencia UAT 2016;10(2): 44

Plascencia A, Mendoza G, Vásquez C, Zinn R. Factores que influyen en el valor nutricional de las grasas utilizadas en las dietas para bovinos de engorda en confinamiento. Interciencia 2005;30(3):134-142.

Poorghasemi M, Seidavi A, Qotbi AAA, Laudadio V, Tufarelli V. Influence of dietary fat source on growth performance responses and carcass traits of broiler chicks. Asian-Australasian Journal of Animal Sciences 2013;26(5): 705.

Salinas J, Ramirez RG, Domínguez MM, Reyes-Bernal N, Trinidad-Larraga N, Montano MF. Effect of calcium soaps of tallow on growth performance and carcass characteristics of Pelibuey lambs. Small Ruminant Research 2006;66(1-3):135-139.

Sklan D. Digestion and absorption of lipids in chicks fed triglycerides or free fatty acids: synthesis of monoglycerides in the intestine. Poultry Science 1979:58(4):885-889.

Tabeidian SA, Sadeghi GH. Use of plant based calcium salt of fatty acids in broiler diets. International Journal of Poultry Science 2006;5(1):96-98.

Takeoka GR, Full GH, Dao LT. Effect of heating on the characteristics and chemical composition of selected frying oils and fats. Journal of Agricultural and Food Chemistry 1997;45(8):3244-3249. 
Villanueva-Lopez DA, Infante-Rodríguez F, Nájera-Pedraza OG, Barrios-García HB,

Salinas-Chavira J

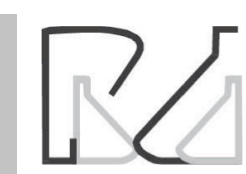

Effect of Dietary Frying Fat, Vegetable Oil and

Calcium Soaps Of Palm Oil on the Productive Behavior and Carcass Yield of Broiler Chickens
UNA - Unión Nacional de Avicultores. Compendio de Indicadores Económicos del Sector Avícola 2018 [cited 2020 Jan 18]. Available from: https://www.una.org.mx/indicadores-economicos/.

Valencia ME, Watkins SE, Waldroup $A L$, Waldroup $\mathrm{PW}$, Fletcher DL. Utilization of crude and refined palm and palm kernel oils in broiler diets. Poultry Science 1993;72(12):200-215.

Vázquez-Añón M, Jenkins T. Effects of feeding oxidized fat with or without dietary antioxidants on nutrient digestibility, microbial nitrogen, and fatty acid metabolism. Journal of Dairy Science 2007;90(9):4361-4867.

Vázquez-Añón $M$, Nocek J, Bowman G, Hampton T, Atwell C, Vázquez $P_{\text {, }}$ et al. Effects of feeding a dietary antioxidant in diets with oxidized fat on lactation performance and antioxidant status of the cow. Journal of Dairy Science 2008;91(8):3165-3172.
Wiseman J, Salvador F. The influence of free fatty acid content and degree of saturation on the apparent metabolizable energy value of fats fed to broilers. Poultry Science 1991;70(3), 573-582.

Waldroup PW, Watkins SE, Saleh EA. Comparison of two blended animalvegetable fats having low or high free fatty acid content. Journal of Applied Poultry Research 1995;4(1):41-48.

Wu H, Gong LM, Guo L, Zhang L, Li JT. Effects of the free fatty acid content in yellow grease on performance, carcass characteristics, and serum lipids in broilers. Poultry Science 2011;90(9):1992-1998. 
